University of Nebraska - Lincoln

DigitalCommons@University of Nebraska - Lincoln

Uniformed Services University of the Health

Sciences

U.S. Department of Defense

1991

\title{
Evaluation of the Role of Shiga and Shiga-like Toxins in Mediating Direct Damage to Human Vascular Endothelial Cells
}

\author{
Vernon L. Tesh \\ Uniformed Services University of the Health Sciences \\ James E. Samuel \\ Biocarb, Inc. \\ Liyanage P. Perera \\ Uniformed Services University of the Health Sciences \\ John B. Sharefkin \\ Uniformed Services University of the Health Sciences \\ Alison D. O'Brien \\ Uniformed Services University of the Health Sciences, alison.obrien@usuhs.edu
}

Follow this and additional works at: https://digitalcommons.unl.edu/usuhs

Part of the Medicine and Health Sciences Commons

Tesh, Vernon L.; Samuel, James E.; Perera, Liyanage P.; Sharefkin, John B.; and O'Brien, Alison D., "Evaluation of the Role of Shiga and Shiga-like Toxins in Mediating Direct Damage to Human Vascular Endothelial Cells" (1991). Uniformed Services University of the Health Sciences. 113.

https://digitalcommons.unl.edu/usuhs/113

This Article is brought to you for free and open access by the U.S. Department of Defense at DigitalCommons@University of Nebraska - Lincoln. It has been accepted for inclusion in Uniformed Services University of the Health Sciences by an authorized administrator of DigitalCommons@University of Nebraska Lincoln. 


\title{
Evaluation of the Role of Shiga and Shiga-like Toxins in Mediating Direct Damage to Human Vascular Endothelial Cells
}

\author{
Vernon L. Tesh, James E. Samuel, * Liyanage P. Perera, \\ John B. Sharefkin, and Alison D. O'Brien
}

Departments of Microbiology and Surgery, Uniformed Services University of the Health Sciences, Bethesda, Maryland

\begin{abstract}
Infection with Shiga toxin- and Shiga-like toxin-producing strains of Shigella dysenteriae and Escherichia coli, respectively, can progress to the hemolytic-uremic syndrome. It has been hypothesized that circulating Shiga toxin, Shiga-like toxins, and endotoxins may contribute to the disease by directly damaging glomerular endothelial cells. The effects of these toxins on HeLa, Vero, and human vascular endothelial cells (EC) were examined. Confluent EC were sensitive to Shiga toxin but were at least $\mathbf{1 0}^{6}$-fold less sensitive to the toxins than were Vero cells. Shiga toxin was the predominant cytotoxic factor. Lipopolysaccharides were not cytotoxic and did not augment Shiga toxin-mediated toxicity. Lower doses of Shiga toxin caused cytotoxicity when coincubated with tumor necrosis factor. The relative resistance of EC to Shiga toxin and Shiga-like toxins may be due to reduced toxin binding, as low levels of globotriaosylceramide $\left(\mathbf{G b}_{3}\right)$, the toxin-specific receptor, were found in EC membranes.
\end{abstract}

Inflammatory bacterial colitis caused by infection with Shigella species continues to be a major cause of morbidity and mortality in underdeveloped countries, especially among young children [1]. Of particular interest is Shigella dysenteriae type 1, which is capable of causing epidemic outbreaks of dysentery. In addition, it has recently been shown that some strains of Escherichia coli, particularly E. coli serotype O157:H7, can cause hemorrhagic colitis [2, 3]. Collectively, these E. coli strains are referred to as enterohemorrhagic $E$. coli (EHEC). S. dysenteriae type 1 and EHEC share the characteristic of producing high levels of protein toxins called Shiga toxin or Shiga-like toxins (SLTs or Verotoxins), respectively. EHEC may produce two antigenically distinct toxins, designated SLT-I and SLT-II. SLT-I is essentially identical to Shiga toxin, and its cytotoxic activity for Vero or HeLa cells can be neutralized with anti-Shiga antibodies [4, 5]. SLT-II is $56 \%$ homologous to Shiga toxin/SLT-I at the deduced amino acid level, and its cytotoxicity is not blocked by anti-Shiga toxin antibodies $[5,6]$.

Shiga toxin and SLTs are holotoxins that consist of a single $32-$ to $33-\mathrm{kDa}$ A subunit in association with a pentamer of 7.7-kDa B subunits [7]. The A subunit is a specific $N$-glycosidase that selectively cleaves a single adenine residue

Received 16 August 1990; revised 13 February 1991.

The opinions or assertions herein are the private ones of the authors and are not to be construed as official or reflecting the views of the Department of Defense or of the Uniformed Services University of the Health Sciences. Grant support: National Institutes of Health (AI-20148).

Reprints or correspondence: Dr. Alison O'Brien, Department of Microbiology, Uniformed Services University of the Health Sciences, 4301 Jones Bridge Rd., Bethesda, MD 20814.

* Present address: Biocarb, Inc., Gaithersburg, Maryland.

The Journal of Infectious Diseases 1991;164:344-52

This article is in the public domain

0022-1899/91/6403-0017 from the $28 \mathrm{~S}$ rRNA component of the 60 S eukaryotic ribosome complex $[8,9]$. The B subunit mediates binding of the holotoxin to specific glycolipid receptors in mammalian cell membranes [10-13]. Although the precise role of Shiga toxin and the SLTs in the pathogenesis of bacillary dysentery and hemorrhagic colitis, respectively, is not fully understood, there is now convincing evidence to suggest that the toxins are important virulence factors in the development of bloody, edematous vascular lesions of the colon [14]. The toxins may also participate in the direct killing of colonic epithelial cells and may provoke fluid secretion and diarrhea in the host [7].

Perhaps the most serious sequela of colitis caused by $S$. dysenteriae type 1 or EHEC is the progression of the disease to the hemolytic-uremic syndrome (HUS), which is characterized by acute renal failure, thrombotic microangiopathy, and thrombocytopenia [15]. Histopathologic studies of the kidneys of HUS patients have shown profound alterations in the glomeruli. More specifically, glomerular endothelial cells (EC) appear swollen, and there is abundant fibrin deposition and inflammatory cell influx in the lumina of the glomeruli [16]. These observations, as well as the critical role of EC in maintaining normal blood flow [17], have led to the concept that systemic Shiga toxin or SLTs may specifically target the glomerular EC for damage and thereby contribute to the development of HUS. In support of this hypothesis, Obrig et al. [18] showed that Shiga toxin preparations are cytotoxic for human umbilical vein EC (HUVEC) in vitro.

In the experiments reported here, we assessed the cytotoxic potential of crude Shiga toxin, SLT-II, and affinity-purified Shiga toxin for confluent human saphenous vein EC (HSVEC) and HUVEC monolayers. In addition, we compared Shiga toxin-mediated EC and Vero cell cytotoxicity and examined the role of lipopolysaccharides (LPS) and recombinant human tumor necrosis factor- $\alpha$ in direct EC cyto- 
toxicity. Finally, we analyzed toxin binding to intact EC and quantitated levels of toxin receptor in EC membranes.

\section{Materials and Methods}

Bacterial strains and plasmids. S. dysenteriae type 1 strain $3818 \mathrm{~T}$ produces high levels of Shiga toxin and was isolated from a patient with severe dysentery in Central America [19]. E. coli O157:H7 strain 933 produces both SLT-I and II and was isolated from an outbreak of hemorrhagic colitis in the United States $[2,5]$. Toxins used in this study were derived from $E$. coli DH $5 \alpha$ (Bethesda Research Laboratories, Gaithersburg, MD) transformed with recombinant plasmids containing the cloned toxin genes. E. coli (pLPSH3) harbors the plasmid pBR328 that contains the entire Shiga toxin operon on a 5.9-kb BglII-SalI insert subcloned from pNAS10 $[4,20]$. E. coli (pLP32) harbors a Bluescribe vector ( $\mathrm{pBS}[-]$ phagemid kit; Stratagene, La Jolla, CA) with a 3.0-kb SphI-KpnI fragment from pNN76 encoding SLT-II $[21,22]$. Clones producing high levels of toxin were maintained under BL3 + EK1 containment [23].

Toxin preparations. LPS were prepared from $S$. dysenteriae $3818 \mathrm{~T}$ and E. coli 933 by the hot aqueous-phenol method of Westphal and Jann [24]. The pooled aqueous phases were dialyzed against nine changes of double-distilled, deionized $\mathrm{H}_{2} \mathrm{O}$, concentrated 10-fold (Amicon, Danvers, MA), and lyophilized. LPS preparations contained $<5 \mu \mathrm{g} / \mathrm{ml}$ protein (BCA protein assay; Pierce Chemical, Rockford, IL). E. coli O111:B4 LPS was purchased from Sigma Chemical (St. Louis). Concentrated crude Shiga toxin and SLT-II were prepared from E. coli (pLPSH3) and E. coli (pLP32), respectively. The strains were grown at $37^{\circ} \mathrm{C}$ in $50 \mathrm{ml}$ of Luria broth (LB) containing 250 $\mu \mathrm{g} / \mathrm{ml}$ ampicillin for 24 or $48 \mathrm{~h}$ with constant agitation. The bacteria were pelleted by centrifugation, washed, and resuspended in $5.0 \mathrm{ml}$ of LB. The bacteria were disrupted by sonication and the lysates cleared by centrifugation at $12,000 \mathrm{~g}$ for 15 $\mathrm{min}$. Toxins in the clarified lysates were concentrated by precipitation with $60 \%$ saturated ammonium sulfate. The precipitates were resuspended in $5.0 \mathrm{ml}$ of PBS and dialyzed overnight against PBS. Toxins prepared in this manner reproducibly contained $\sim 10^{8}-10^{9} \mathrm{CD}_{50} / \mathrm{ml}$ when assessed by the Vero cell cytotoxicity assay. Purified Shiga toxin was prepared from this crude starting material as described $[22,25]$. Briefly, crude toxin was passed over a DEAE-Sepharose column equilibrated with 0.05 $M$ TRIS buffer and eluted with a gradient of $0-1.0 \mathrm{M} \mathrm{NaCl}$ in $0.05 M$ TRIS buffer. Fractions cytotoxic for Vero cells were pooled and passed over a chromatofocusing column. Cytotoxic fractions were pooled, dialyzed, and passed over an antitoxin affinity column. Shiga toxin was eluted with $0.05 \mathrm{M}$ glycine, dialyzed against PBS, and stored at $4^{\circ} \mathrm{C}$ until used. Purified Shiga toxin preparations contained $<0.1 \mathrm{ng} / \mathrm{ml}$ endotoxin as assessed by limulus amoebocyte lysate gelation (Endotect; Schwarz/Mann Biotech, Cleveland).

Recombinant human tumor necrosis factor- $\alpha$ (rhTNF $\alpha$ ). rhTNF $\alpha$ (lot NBP-802A; $2.7 \times 10^{7}$ units $/ \mathrm{mg}$ ) was the gift of A. Creasey (Cetus, Emeryville, CA). Before use in cytotoxicity assays, the lyophilized cytokine was resuspended to $260 \mu \mathrm{g} / \mathrm{ml}$ in sterile pyrogen-free water (Travenol Laboratories, Deerfield,
IL). The stock preparations were then diluted in growth medium as needed.

Tissue culture. Vero and HeLa cells were maintained in Eagle's MEM (Flow Laboratories, McLean, VA) supplemented with $10 \%$ fetal bovine serum, $10 \mathrm{mM}$ L-glutamine, 50 units $/ \mathrm{ml}$ penicillin, and $50 \mu \mathrm{g} / \mathrm{ml}$ streptomycin. EC were harvested from adult human saphenous veins (HSV) obtained during coronary bypass operations as previously described [26]. Vein segments $(\sim 2.5 \mathrm{~cm})$ were transported to the laboratory in chilled blood with 100 units $/ \mathrm{ml}$ preservative-free heparin (Sigma). The HSV were cannulated and flushed with cold $\mathrm{Ca}^{++}$- and $\mathrm{Mg}^{++}$-free Dulbecco's PBS (PBS-CMF; GIBCO, Grand Island, NY). HSV were ligated after filling to slight distension with $0.1 \%$ CLS II collagenase (Worthington Diagnostic Systems, Freehold, NJ) and $0.5 \%$ bovine serum albumin (BSA) in PBS-CMF and immersed in Hanks' balanced salt solution (GIBCO) for $15 \mathrm{~min}$ at $37^{\circ} \mathrm{C}$. HSV were flushed with $10 \mathrm{ml}$ of cold complete medium (CM) composed of Medium 199 (GIBCO) with $20 \%$ fetal bovine serum (Hyclone Laboratories, Logan, UT), $100 \mu \mathrm{g} / \mathrm{ml}$ heparin (Sigma), $100 \mu \mathrm{g} / \mathrm{ml}$ L-glutamine, 50 units/ml penicillin, $50 \mu \mathrm{g} /$ $\mathrm{ml}$ streptomycin (GIBCO), and $2 \mu \mathrm{g} / \mathrm{ml}$ amphotericin B (Fungizone; GIBCO).

The vein contents were centrifuged $\left(200 \mathrm{~g}, 7 \mathrm{~min}, 4^{\circ} \mathrm{C}\right)$, and the cell pellet was resuspended in $1.0 \mathrm{ml}$ of $\mathrm{CM}$ supplemented with $20 \mu \mathrm{l} / \mathrm{ml}$ EC-mitogen extract prepared from bovine retina using a modification of a previously described method [27, 28]. The cells were placed in single wells of 24-well plates (Falcon; Becton Dickinson Labware, Oxnard, CA) coated with $1 \mu \mathrm{g} / \mathrm{cm}^{2}$ human fibronectin and incubated at $37^{\circ} \mathrm{C}$ in humidified $5 \%$ $\mathrm{CO}_{2}$. The other wells were filled with sterile PBS-CMF to minimize changes in osmolality. Cells were fed every other day with fresh CM containing $10 \mu \mathrm{l} / \mathrm{ml}$ bovine retinal extract (CM-BRE). When primary cultures became confluent, HSVEC were detached using $0.05 \%$ trypsin-0.02\% EDTA, washed in CM with $10 \%$ serum, and resuspended in CM-BRE. Subsequent passages of HSVEC were plated on gelatin-coated $25-\mathrm{cm}^{2}$ tissue culture flasks or 96-well microtiter plates. All experiments were done with HSVEC passaged two to five times in vitro.

HSVEC were characterized by inverted-phase microscopic observation of cell morphology and immunoenzymatic staining for factor VIII-related antigen (Endo-RAP I.D.; Endotech, Indianapolis). Primary HUVEC were the gift of D. Silverman (Department of Microbiology, University of Maryland School of Medicine, Baltimore). HUVEC were passaged and maintained as described above.

Cytotoxicity assays. The cytotoxicity of toxin preparations for Vero cells was determined as described [29]. Vero cells were plated at $\sim 10^{4}$ cells/well in 96-well plates and incubated overnight at $37^{\circ} \mathrm{C}$ in $5 \% \mathrm{CO}_{2}$. Toxin preparations were serially diluted in complete Eagle's MEM medium, and $100 \mu$ of the dilutions was transferred to the cells. Incubation was continued for $48 \mathrm{~h}$. The cells were fixed with formalin and stained with $0.13 \%$ crystal violet. Absorbance was measured at $620 \mathrm{~nm}$. A $50 \%$ cytotoxic dose $\left(\mathrm{CD}_{50}\right)$ represents the reciprocal dilution of toxin necessary to kill $50 \%$ of the Vero cells in a well. The cytotoxic potency of toxin preparations is defined as the number of $\mathrm{CD}_{50}$ per milliliter of toxin preparation. Cytotoxicity of toxin preparations for EC was assessed by hemocytometer counts or 
by spectrophotometry. EC were plated on the interior 24 wells of gelatin-coated 96 -well plates at $\sim 2 \times 10^{4}$ cells per well. Exterior wells were filled with PBS-CMF. When the cells reached confluence, fresh CM-BRE containing the toxin(s) to be assayed were added to triplicate wells in a total volume of $200 \mu \mathrm{l}$. Incubation was continued at $37^{\circ} \mathrm{C}$ in $5 \% \mathrm{CO}_{2}$. Cells that subsequently detached from the gelatin substratum failed to exclude trypan blue, or after extensive washing, did not grow when recultured on gelatin-coated plates.

Viable cells were stained for counting in a hemocytometer by replacing the growth medium with $60 \mu \mathrm{l}$ of $0.1 \%$ crystal violet in $0.1 M$ citric acid ( $\mathrm{pH} 7.26)$. After the cells were incubated with the dye at $37^{\circ} \mathrm{C}$ for $20 \mathrm{~min}$, the wells were scraped with sterile pipette tips, and $15 \mu \mathrm{l}$ of cell suspension was transferred to the hemocytometer. Stained nuclei were then counted. Cells were counted using a microtiter plate reader according to the method of Brasaemle and Attie [30]. Cells were washed with warm PBS$\mathrm{CMF}$, and $100 \mu \mathrm{l}$ of methanol per well was added for $15 \mathrm{~min}$ at room temperature. The methanol was aspirated from the wells, the plates were air dried, and $100 \mu \mathrm{l}$ of $0.1 \%$ crystal violet was added to each well for $5 \mathrm{~min}$. After the dye was removed and the plates dried, each well was washed with $\mathrm{H}_{2} \mathrm{O}$, and the stained cells were solubilized with $100 \mu \mathrm{l}$ of $2 \%$ (wt/vol) sodium deoxycholate. The plates were heated in a microwave oven (Samsung MW5510; setting 2) for $1 \mathrm{~min}$, and agitated (mini-orbital shaker, setting 6; Bellco Glass, Vineland, $\mathrm{NJ}$ ) for $10 \mathrm{~min}$. Absorbance was read at $570 \mathrm{~nm}$. Cell counts were correlated by linear regression analysis of hemocytometer counts of stained nuclei against absorbance measurements of triplicate serial twofold dilutions of EC. This assay produced a linear standard curve between $1.5 \times 10^{3}$ and $6 \times 10^{4}$ cells per well (mean $R$ value, .92). Data were expressed as percentage of viability, which is defined as (number of cells + toxin - background/number of control cells - background) $\times 100$. Background absorbance was derived from staining blank wells. Control cells were incubated with CM-BRE only.

Neutralization assay. Dilutions of toxins were made in appropriate growth media in 96 -well plates $(100 \mu \mathrm{l} /$ well $)$, and 100 $\mu$ l of anti-Shiga toxin monoclonal antibody (MAb 13C4) was added to each well. The plates were agitated, incubated at $37^{\circ} \mathrm{C}$ in $5 \% \mathrm{CO}_{2}$ for $1 \mathrm{~h}$, and kept overnight at $4^{\circ} \mathrm{C}$. Toxin-antitoxin mixtures $(100 \mu \mathrm{l})$ were then added to Vero cells or EC, and cytotoxicity was determined as described above. An isotypematched MAb directed against the B subunit of cholera toxin [31] did not affect cytotoxicity in this assay.

Analysis of toxin binding to whole cells. A modification of an immunofluorescence protocol using a computer-assisted scanning laser instrument (ACAS 470; Meridian Instruments, Okemos, MI) was devised to compare Shiga toxin binding to EC versus Vero and HeLa cells [20,32]. Cells were trypsinized and adjusted to $\sim 5 \times 10^{5}$ cells $/ \mathrm{ml}$ in cold diluent buffer (phenol red-free Earle's balanced salt solution [EBSS; GIBCO] containing $10 \%$ fetal bovine serum and $0.1 \% \mathrm{NaN}_{3}$ ). Concentrated crude Shiga toxin $\left(50 \mu \mathrm{l} ; \sim 10^{9}\right.$ Vero cell $\left.\mathrm{CD}_{50} / \mathrm{ml}\right)$ was added to $450 \mu \mathrm{l}$ of cells in Eppendorf tubes and agitated at $4^{\circ} \mathrm{C}$ for 60 min. Unless otherwise noted, all binding and washing steps were done at $4^{\circ} \mathrm{C}$. Unbound toxin was removed by three washes with cold diluent buffer.
The cells were resuspended in $500 \mu \mathrm{l}$ of a 1:100 dilution of primary antibody and agitated for $45 \mathrm{~min}$. Primary antibodies used were 4F7, monoclonal IgGl directed against the A subunit of Shiga toxin [33]; 13C4, monoclonal IgG I directed against the B subunit of Shiga toxin [34]; and BC5BB 12, monoclonal IgG1 directed against the B subunit of SLT-II [35]. Unbound antibody was removed by three washes with diluent buffer, and secondary antibody (500 $\mu \mathrm{l}$ of a 1:100 dilution of a fluorescein isothiocyanate-conjugated goat $\mathrm{F}\left[\mathrm{ab}^{\prime}\right]_{2}$ anti-mouse IgG; Cappel Laboratories, Westchester, PA) was added to the cells. After unbound secondary antibody was washed out, the cells were treated with $100 \mu \mathrm{l}$ of a fluorescent nonspecific membrane probe, 1, 1'-dioctadecyl-3,3,3',3'-tetramethyl indocarbocyanine perchlorate $(5 \mu \mathrm{g} / \mathrm{ml}$ in $1 \%$ ethanol and serum-free EBSS; Molecular Probes, Eugene, OR) at $37^{\circ} \mathrm{C}$ for $10 \mathrm{~min}$.

After extensive washing with cold serum-free EBSS, the cells were transferred to flat-bottomed 96 -well plates and centrifuged for $10 \mathrm{~min}(200 \mathrm{~g})$ at $4^{\circ} \mathrm{C}$. The plates were immediately scanned using the Meridian ACAS 470 equipped with a 5-W argon laser tuned to $488 \mathrm{~nm}$. Laser power was adjusted to $200 \mathrm{~mW}$ and scan strength adjusted to $35 \%$. The collimated first-order beam was directed through a standard dichroic filter cube. (See [32] for a more detailed description of laser parameters.) Qualitative analysis of Shiga toxin binding was done by microcomputer conversion of fluorescent emissions into a 15-pseudocolor scan based on fluorescence intensity.

Thin-layer chromatography of toxin-binding glycolipids. Total lipid extracts from HSVEC, HUVEC, Vero, and HeLa cells were subjected to chromatography on aluminum-backed silica gel thin-layer chromatography plates (silica gel 60; Merck AG, Darmstadt, FRG) with $\mathrm{CHCl}_{3}-\mathrm{CH}_{3} \mathrm{OH}-0.25 \%$ aqueous $\mathrm{KCl}$ (5:4:1) as previously described [22, 36]. Purified glycolipids served as controls. After chromatography, the chromatography plates were coated with $0.1 \%$ polyisobutylmethacrylate (Polyscience, Warrington, PA), air dried, and sprayed with TBS-BSA (0.1 $M$ TRIS-HCl [pH 7.4], $0.15 \mathrm{M} \mathrm{NaCl}, 1 \%$ BSA). The plates were overlaid with $\sim 10^{5} \mathrm{CD}_{50} / \mathrm{ml}$ Shiga toxin in TBS-BSA. After incubation at $4^{\circ} \mathrm{C}$, the plates were extensively washed with PBS and overlaid with MAb $13 \mathrm{C} 4$ diluted in TBS-BSA. Goat anti-mouse IgG labeled with ${ }^{125} \mathrm{I}$ was used as secondary antibody. The plates were washed, air dried, and specific binding was visualized by autoradiography. Relative amounts of toxin-binding glycolipids were estimated from peak areas of densitometric scans obtained with a densitometer (CS9000U; Shimadzu, Kyoto, Japan) and compared with serial dilutions of the control glycolipid globotriaosylceramide $\left(\mathrm{Gb}_{3}\right)$. Autoradiographs of several exposure times for each thin layer chromatography plate were scanned to ensure the peak areas were within the linear range of the densitometer.

Statistical analysis. The significance of differences between means of samples was determined by Student's two-tailed $t$ test. $P<.025$ was considered significant.

\section{Results}

Role of Shiga toxin, SLT-II, and LPS in direct EC cytotoxicity. To assess the cytotoxic potential of Shiga toxin for HSVEC, various dilutions of crude Shiga toxin preparations 


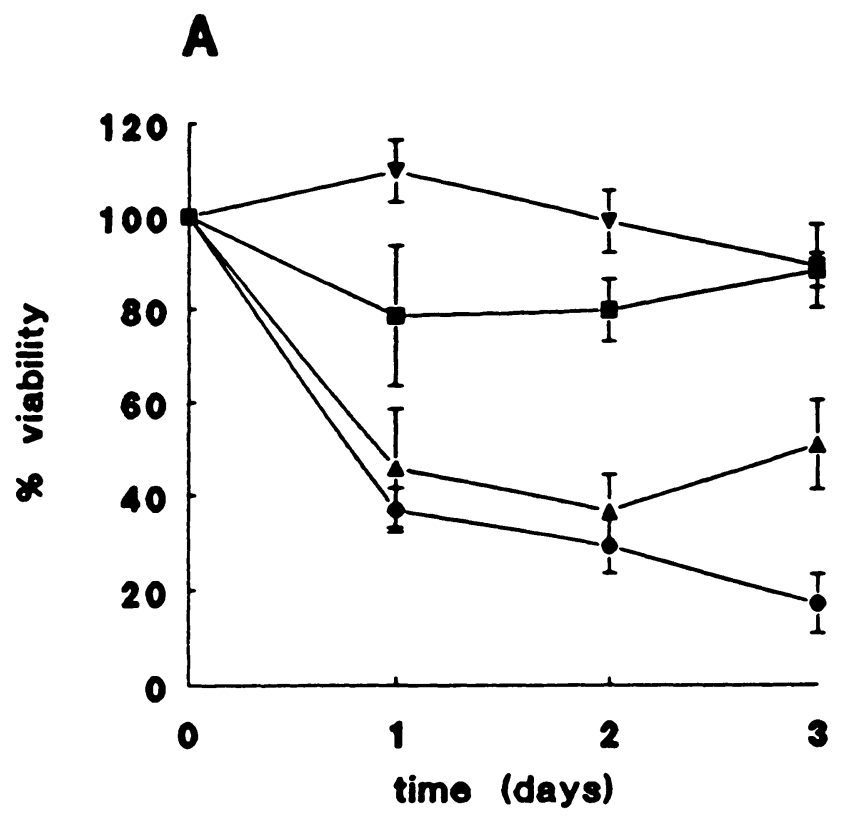

B

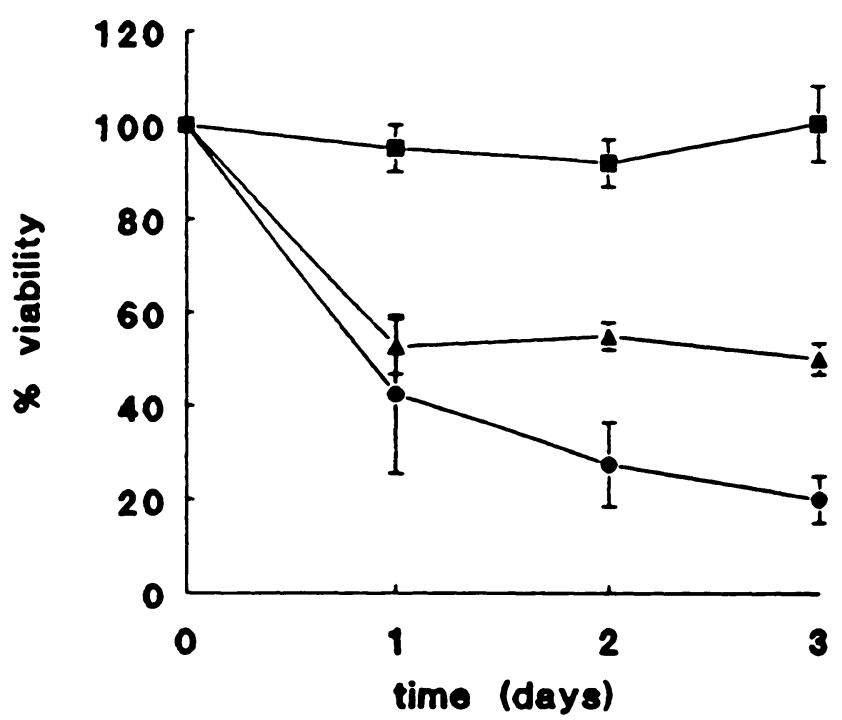

Figure 1. Effect of crude and purified Shiga toxin on endothelial cell viability. Confluent human saphenous vein endothelial cell (HSVEC) monolayers were incubated with dilutions of (A) crude or (B) affinity-purified Shiga toxin. At the indicated time points, the numbers of viable, adherent cells were determined and compared to HSVEC cultured in the absence of toxin. Toxin dilutions were made on the basis of Vero cell $50 \%$ cytotoxic doses $\left(\mathrm{CD}_{50}\right)$ : ๑, $10^{9} ; \Delta, 10^{7} ; \mathbf{\square}, 10^{5} ; \nabla, 10^{3}\left(\right.$ all $\left.C_{50}\right)$. Error bars indicate SD.

were incubated with confluent EC monolayers, and the number of viable cells remaining attached to gelatin-coated wells was determined by hemocytometer counting or spectrophotometry. The incubation of HSVEC with the highest dilutions of crude Shiga toxin resulted in a dose-dependent kill- ing of the cells (figure 1A). Cytotoxicity occurred within the first $24 \mathrm{~h}$ of incubation, and EC viability remained reduced relative to control cells over $72 \mathrm{~h}$. When HUVEC were used as target cells, the kinetics and dose response of Shiga toxinmediated toxicity were essentially identical to those of HSVEC (data not shown). Treatment of both EC types with crude SLT-II preparations killed the cells in a manner similar to crude Shiga toxin (data not shown). Finally, treatment of both EC types with affinity-purified Shiga toxin resulted in killing that was similar to that observed with crude toxin preparations (figure 1B). Dilutions of the toxins were made based on cytotoxicity for Vero cells. From these data, we estimated that $1 \mathrm{EC} \mathrm{CD}_{50}$ was roughly equivalent to $10^{7}$ Vero cell $\mathrm{CD}_{50}$, or $\sim 1.4 \times 10^{-8} M$ Shiga toxin. These results suggest, therefore, that while confluent human EC derived from large veins are sensitive to Shiga toxin, they are at least $10^{6}$-fold less susceptible than Vero cells.

The observation that purified Shiga toxin killed EC in a manner similar to crude toxin preparations suggested that Shiga toxin was the primary mediator of cytotoxicity for EC. However, the effects of small amounts of endotoxin present in the toxin preparations could not be discounted, especially in light of recent evidence that nanogram quantities of endotoxins can have profound effects on EC function [37-39]. To more fully assess the role of Shiga toxin in EC cytotoxicity, we incubated the cells with varying amounts of affinitypurified Shiga toxin in the presence or absence of anti-Shiga toxin MAb (table 1). Even at the highest toxin concentration tested, cytotoxicity was completely neutralized by antitoxin antibody. Antibody alone had no effect on cell viability, and the addition of an irrelevant, isotype-matched MAb did not block Shiga toxin cell killing (data not shown). The observation that MAb directed against Shiga toxin neutralizes cytotoxicity provides further evidence in support of the concept that, in vitro, Shiga toxin is the predominant mediator of direct EC cytotoxicity.

In light of clinical evidence suggesting that patients with HUS are frequently endotoxemic [40] as well as histopatho-

Table 1. Neutralization of endothelial cell (EC) cytotoxicity with anti-Shiga toxin monoclonal antibody (MAb).

\begin{tabular}{|c|c|c|c|c|}
\hline \multirow{3}{*}{$\begin{array}{l}\text { Toxin dose } \\
\text { in } \mathrm{CD}_{50} / \mathrm{ml}^{*}\end{array}$} & \multicolumn{4}{|c|}{ Duration of EC exposure to toxin } \\
\hline & \multicolumn{2}{|c|}{$24 \mathrm{~h}$} & \multicolumn{2}{|c|}{$72 \mathrm{~h}$} \\
\hline & No. MAb & With MAb & No. MAb & With MAb \\
\hline $10^{9}$ & $42.2 \pm 17.3$ & $104.6 \pm 3.2$ & $20.0 \pm 5.0$ & $96.7 \pm 8.6$ \\
\hline $10^{7}$ & $52.7 \pm 6.0$ & $100.4 \pm 6.5$ & $50.1 \pm 4.9$ & $110.0 \pm 2.3$ \\
\hline $10^{5}$ & $91.6 \pm 4.9$ & $109.1 \pm 3.2$ & $100.1 \pm 8.8$ & $106.6 \pm 3.0$ \\
\hline
\end{tabular}

NOTE. Confluent EC were incubated for 24 or $72 \mathrm{~h}$ with the indicated doses of Shiga toxin, in the presence or absence of anti-Shiga toxin MAb. The number of substratum-adherent cells was determined as described in Materials and Methods. Data are percentages of viable EC \pm SD.

* Number of Vero cell $\mathrm{CD}_{50} / \mathrm{ml}$. 


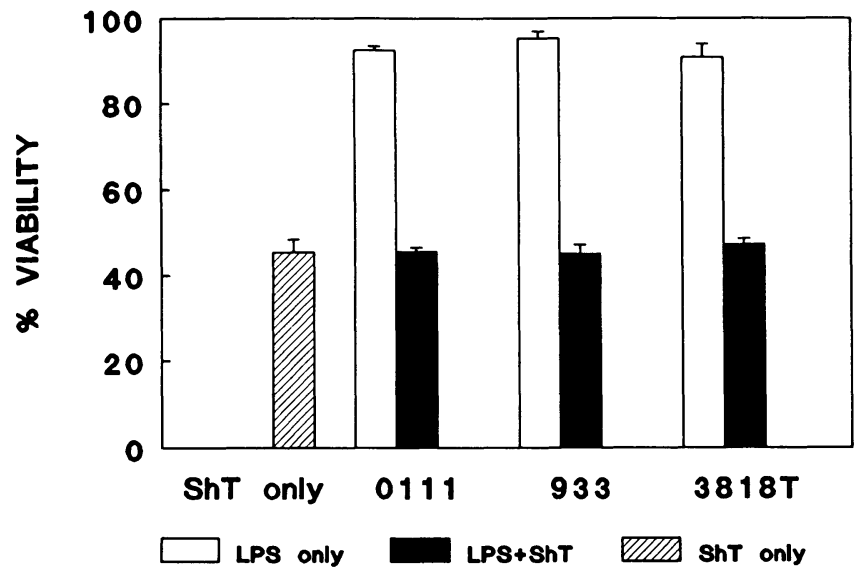

Figure 2. Effect of Shiga toxin (ShT) versus lipopolysaccharides (LPS) on endothelial cell (EC) viability that was determined after confluent cells were incubated $48 \mathrm{~h}$ with $\sim 1$ EC $50 \%$ cytotoxic dose $\left(1 \mathrm{EC} \mathrm{CD} \mathrm{CD}_{50} \approx 10^{7}\right.$ Vero cell $\left.\mathrm{CD}_{50}\right)$ of purified ShT only; 10 $\mu \mathrm{g} / \mathrm{ml}$ LPS derived from Escherichia coli O111:B4, E. coli $\mathrm{O} 157: \mathrm{H} 7$ strain 933, or Shigella dysenteriae 3818T; or mixtures of $1 \mathrm{EC} \mathrm{CD}_{50}$ ShT and LPS. Error bars = SD. Differences between samples were analyzed by Student's two-tailed $t$ test; $P<.025$ was significant.

logic data suggesting that endotoxins may contribute to the pathologic changes in the kidney characteristic of HUS [41], we queried whether LPS might play a direct role on in vitro EC killing. We demonstrated that purified LPS derived from S. dysenteriae type 1 and EHEC strains were not directly cytotoxic for confluent human EC monolayers (figure 2) or Vero cells (data not shown) at doses as high as $10 \mu \mathrm{g} / \mathrm{ml}$. Furthermore, the coincubation of EC with 10-fold dilutions of LPS and a constant dose of affinity-purified Shiga toxin $\left(\sim 1 \mathrm{EC} \mathrm{CD} \mathrm{CD}_{50}\right)$ did not have a statistically significant effect on EC cytotoxicity in comparison with treatment with Shiga toxin alone $(P \geqslant .025)$. Thus, while the presence of endotoxins in vivo may be an important factor in the pathogenesis of HUS, purified LPS alone does not appear to be a major determinant of direct EC cytotoxicity in vitro.

LPS elicits the synthesis and secretion of TNF $\alpha$ by monocytes and macrophages. TNF $\alpha$ may have pleiotropic effects in vivo, and this cytokine has emerged as a central mediator in initiating and regulating the complex cascade of events that results in a procoagulant and proinflammatory state in the vasculature [42]. However, the contributory effect, if any, of TNF $\alpha$ in Shiga toxin-mediated direct EC cytotoxicity is not clear. We therefore coincubated EC with dilutions of Shiga toxin and rhTNF $\alpha$ and assessed EC cytotoxicity. In the presence of $10 \mathrm{ng} / \mathrm{ml} \mathrm{rhTNF} \alpha$, we detected an $\sim 100$ fold reduction in the Shiga toxin $\mathrm{EC} \mathrm{CD}_{50}$ (table 2).

Comparative analysis of Shiga toxin and SLT-II binding to intact cells. Shiga toxin and SLTs bind to specific glycolipid receptors in the membranes of Vero or HeLa cells [10-13]. Antibody neutralization, competitive binding, and holotoxin dissolution studies have shown binding to be an essen- tial step in target cell intoxication and death [5, 43, 44]. Therefore, reduced binding of Shiga toxin and SLT-II to EC is one possible mechanism to explain the relative insensitivity of EC to the toxins.

To assess toxin binding to intact EC and to compare binding to control cells, we devised an indirect immunofluorescence assay using a computer-assisted laser scanner that converted fluorescence intensity into a pseudocolor spectrum. To monitor toxin binding, EC, Vero, and HeLa cells were treated with equivalent doses of Shiga toxin or SLT-II in suspension, and toxin binding was detected with antitoxin antibodies and fluorescein isothiocyanate-conjugated secondary antibody. The cells were then treated with a nonspecific, fluorescent membrane intercalator to outline the cells and allow comparison of levels of toxin-specific fluorescence within the same field. As shown in figure $3 \mathrm{~A}$, in any given field, virtually every Vero (left panel) or HeLa cell (right panel) was intensely stained after treatment with Shiga toxin. Although every cell showed toxin-specific fluorescence, the intensity varied between cells (i.e., not every cell appeared to bind toxin equivalently). The fluorescence intensity and binding pattern of SLT-II for Vero cells was similar to that seen with Shiga toxin (data not shown). Since essentially every cell bound Shiga toxin, the binding pattern produced by the nonspecific membrane probe was nearly identical to toxin-specific fluorescence (not shown). In contrast to Vero or HeLa cells, when EC were treated with an equivalent dose of Shiga toxin or SLT-II, much lower levels of fluorescence were detected (figure 3B, C, left panels), indicating reduced toxin binding in comparison to Vero and HeLa cells. As with the control cells, however, there appeared to be differences in the amounts of toxin bound to each individual EC. Some cells showed very low levels of fluorescence; others showed a more intense, punctate binding pattern. These data suggest that if toxin binding and cell killing are directly correlated, then EC may be heterogeneous in terms of sensitivity to Shiga toxin. Use of the fluorescent membrane probe (figure $3 \mathrm{~B}, \mathrm{C}$, right panels) clearly showed the outline of the EC

Table 2. Augmentation of endothelial cell cytotoxicity by recombinant human tumor necrosis factor (TNF).

\begin{tabular}{lcc}
\hline & \multicolumn{2}{c}{ \% viability } \\
\cline { 2 - 3 }$\left(\mathrm{CD}_{50} / \mathrm{ml}\right)^{*}$ & No TNF & TNF \\
\hline $10^{7}$ & 56.7 & 37.4 \\
$10^{5}$ & 85.6 & 60.4 \\
$10^{3}$ & 97.7 & 81.4 \\
$10^{1}$ & 105.0 & 90.3 \\
0 & - & 92.1 \\
\hline
\end{tabular}

NOTE. Confluent endothelial cells were incubated in triplicate for $48 \mathrm{~h}$ with the indicated doses of Shiga toxin in presence or absence of rhTNF $\alpha$. The number of substratum-adherent cells was determined as described in Materials and Methods. Data represent mean values of three separate experiments.

* Number of Vero cell $\mathrm{CD}_{50} / \mathrm{ml}$ 

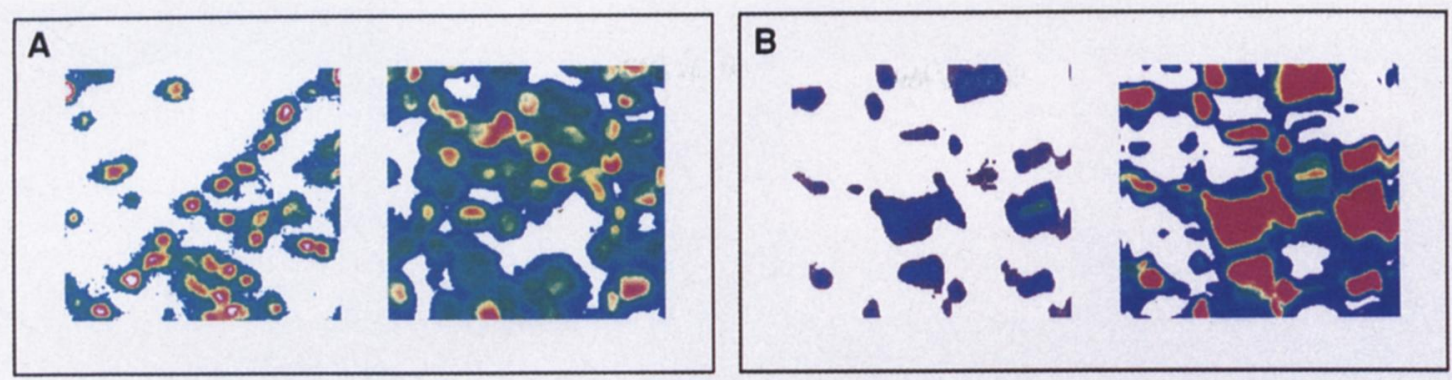

Color Values
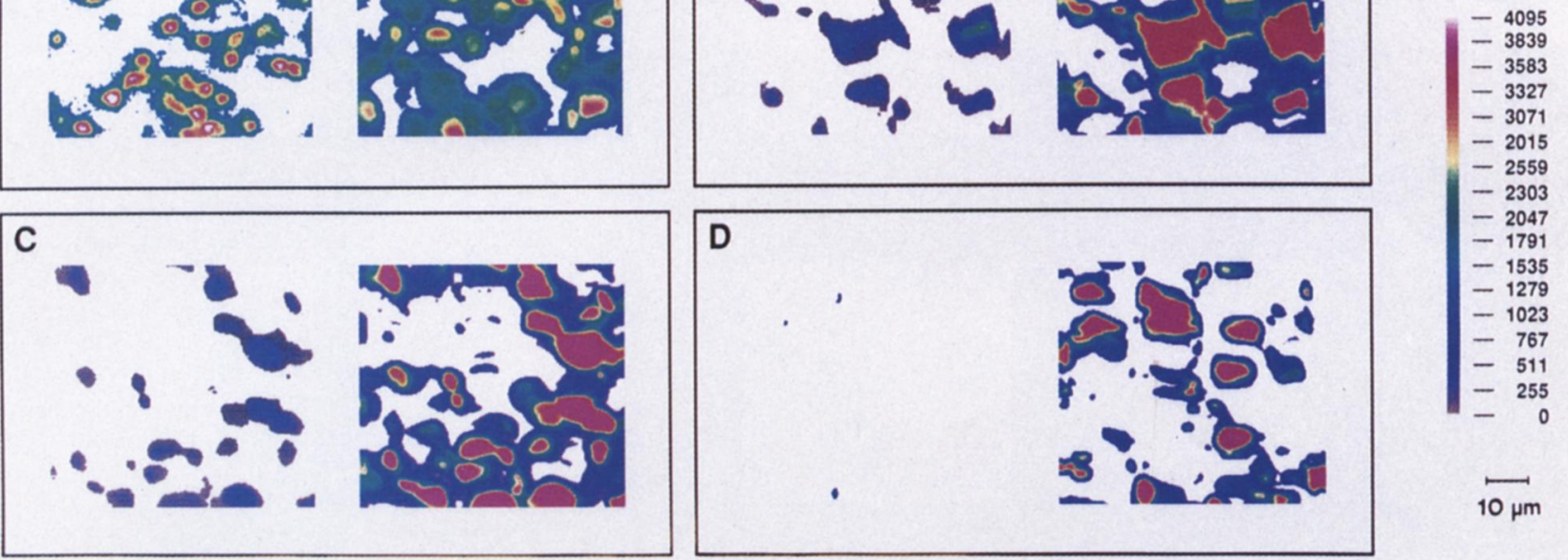

Figure 3. Comparative analysis of Shiga toxin and Shiga-like toxin type II (SLT-II) binding to intact cells. Equivalent numbers of Vero cells, HeLa cells, and endothelial cells (EC) were treated with $10^{9}$ Vero cell $50 \%$ cytotoxic doses of crude toxin preparations at $4{ }^{\circ} \mathrm{C}$ in the presence of $\mathrm{NaN}_{3}$. Bound toxins were detected with anti-toxin monoclonal antibodies and fluorescein-conjugated secondary antibody. The cells were outlined by simultaneous staining with a nonspecific fluorescent membrane probe. Fluorescence was measured using a Meridian ACAS 470 laser scanner in which fluorescence intensity was converted to the 15 color scale at right. Moving up the scale, colors represent increasing fluorescence intensity. A, Vero and HeLa cells (left and right panels, respectively) treated with Shiga toxin. B, EC treated with Shiga toxin (left) and membrane probe (right). C, EC treated with SLT-II (left) and membrane probe (right). D, EC treated with Escherichia coli DH5 $\alpha$ concentrated sonicated lysate, (left) and membrane probe (right).

present in the fields. As a control, concentrated sonicated lysates were prepared from E. coli DH5 $\alpha$ in a manner analogous to that used to concentrate Shiga toxin (see Materials and Methods). The control lysates showed no binding to EC (figure 3D, left). In addition, the deletion of primary or secondary antibody from the assay showed that nonspecific background fluorescence was very low in this procedure (data not shown). Therefore, the fluorescence detectable in Shiga toxin-treated cells is specifically due to toxin binding. These data suggest that one reason EC are less sensitive than Vero or HeLa cells to the cytotoxic effect of Shiga toxin may be low levels of toxin binding to the cells.

Comparative quantitative analysis of toxin-specific glycolipid receptors in EC. Toxin-binding glycolipids present in Vero and HeLa cells and EC were detected by the direct binding of saturating amounts of Shiga toxin to thin-layer chromatograms of serial dilutions of membrane total glycolipid extracts (figure 4, lanes 6-15). Glycolipid standards were used to compare the glycolipids present in each cell line (figure 4, lanes 1-5, 16). In contrast to Vero and HeLa cells, the amount of toxin-binding glycolipids detected in EC membrane extracts prepared from equivalent cell wet weights was greatly reduced. Bound toxin was detected with Shiga toxin-specific MAb and ${ }^{125}$ I-labeled goat anti-mouse IgG antibody. Since the amount of toxin-specific glycolipids present in membrane extracts was previously shown to correlate directly with the amount of bound toxin [45], we quanti- tated the relative amounts of toxin-binding glycolipids by direct densitometric scanning of the autoradiographs. HUVEC and HSVEC contained 0.06 and $0.03 \mathrm{nM} \mathrm{Gb} 3 / \mathrm{mg}$ of cells, respectively. In contrast, Vero and HeLa cells contained 80 and $25 \mathrm{nMGb}_{3} / \mathrm{mg}$ of cells, respectively. Thus, the diminished toxin-binding glycolipid content of EC compared with Vero and HeLa cells directly correlated with reduced Shiga toxin sensitivity and toxin binding.

\section{Discussion}

The experiments reported here were designed to examine the role of crude or purified Shiga toxin, SLT-II, LPS, and recombinant cytokines in killing confluent human vascular endothelial cells and to compare the EC cytotoxicity with that of other cell lines. The incubation of EC with purified Shiga toxin resulted in a reduction in the numbers of viable cells remaining attached to gelatin-coated dishes, and this activity was neutralized by anti-Shiga toxin MAb, suggesting that Shiga toxin was the primary mediator of cytotoxicity in vitro. These results support and extend the findings of Obrig et al. [18], who demonstrated that rabbit polyclonal antiShiga toxin antibodies, as well as heat denaturation, totally neutralize the EC cytotoxic potential of Shiga toxin preparations. These investigators also showed, however, that Shiga toxin, to a dose of $10^{-7} \mathrm{M}$, had a delayed ( $\geqslant 48 \mathrm{~h}$ ) cytotoxic effect on confluent HUVEC [18]. In contrast to their studies, 


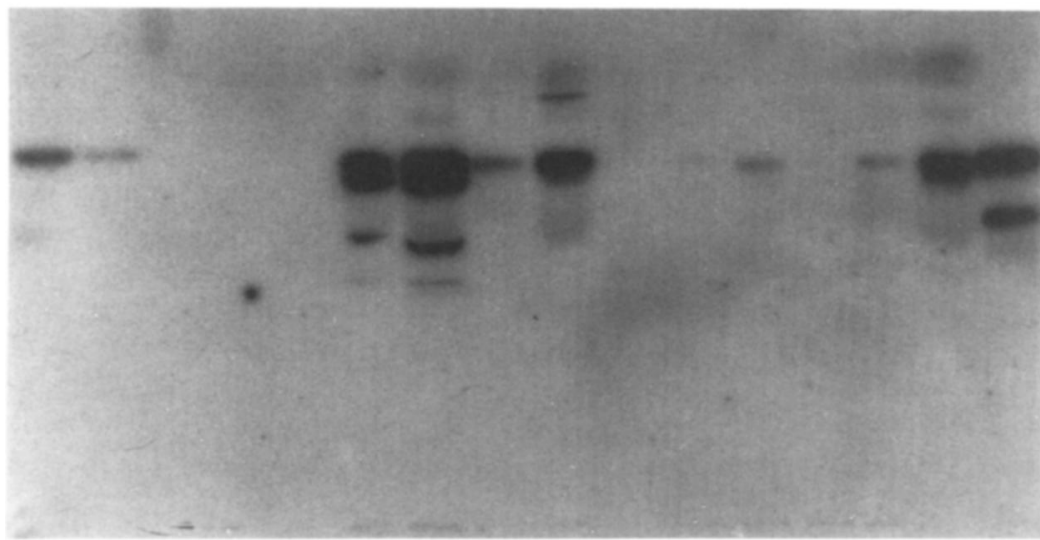

\section{$-\mathrm{CDH}$ \\ - Gb3 \\ - Gb4}

- ORIGIN
Figure 4. Quantitation of toxinspecific glycolipid receptor in human saphenous vein endothelial cells (HSVEC), human umbilical vein endothelial cells (HUVEC), Vero cells, and HeLa cells. Shiga toxin was bound to glycolipids separated by thin-layer chromatography, detected with anti-Shiga toxin monoclonal antibody and ${ }^{125}$ I-labeled goat anti-mouse $\operatorname{IgG}$ antibody, and visualized by autoradiography. By lane: 1-5, 100, 50, 10,5 , and $1 \mathrm{ng}$ globotriaosylceramide $\left(\mathrm{Gb}_{3}\right)$, respectively; 6, 7, glycolipids from 1 and $3 \mathrm{mg}$ of Vero cells, respectively; 8,9 , glycolipids from 1 and $3 \mathrm{mg}$ of HeLa cells, respectively; 10-12, glycolipids from 1,3 , and $10 \mathrm{mg}$ of HSVEC, respectively; 13-15, glycolipids from 1, 3 , and $10 \mathrm{mg}$ of HUVEC, respectively; $16,1 \mu \mathrm{g}$ each of standard glycolipids lactosylceramide $(\mathrm{CDH})$, $\mathrm{Gb}_{3}$, and globotetraosylceramide $\left(\mathrm{Gb}_{4}\right)$. All cell masses are expressed according to wet weight. we detected a more rapid loss of EC viability, occurring within the first $24 \mathrm{~h}$ of incubation with toxin. These differences in kinetics may be due to differences in the metabolic activity of the EC used in the cytotoxicity assays. Obrig et al. [18] cultured different concentrations of HUVEC at $37^{\circ} \mathrm{C}$ for 12-24 h, and these cells were termed confluent or nonconfluent. We seeded EC, monitored growth using an inverted-phase microscope, and allowed the cells to replicate to a confluent state over 3-5 days. Since Shiga toxin acts by inhibiting protein synthesis, differences in target cell metabolic activity may have drastic effects on Shiga toxin sensitivity.

The amount of toxin added to EC was based on the cytotoxicity of the toxin preparations for Vero cells, a cell line that has been used to characterize toxin activity and toxin-receptor interaction [7]. While EC are susceptible to Shiga toxin, they are at least $10^{6}$-fold less sensitive than Vero cells. On the basis of the cytotoxic potential of Shiga toxin for Vero cells $\left(1 \mathrm{CD}_{50} \sim 1 \mathrm{pg}\right.$ of toxin), we estimate that $1 \mathrm{EC} \mathrm{CD}_{50}$ is $\sim 1.4 \times 10^{-8} M$ or $\sim 10 \mu \mathrm{g}$ of toxin. As previously reported for other cytotoxicity assays using Shiga toxin and SLTs [46, 47], we noted a shallow dose response curve, that is, incubation of EC with concentrations of Shiga toxin that differ 100fold produced only slight changes in percentages of viability (compare $10^{9}$ vs. $10^{7} \mathrm{CD}_{50}$, figure 1). In addition, we isolated viable $\mathrm{EC}$, even when the cells were incubated with $\sim 10 \mathrm{EC}$ $\mathrm{CD}_{50}$ of Shiga toxin. Although previous studies have clearly demonstrated differential cytotoxicity between confluent and nonconfluent HUVEC [18], our data suggest that even within a population of confluent $\mathrm{EC}$, there may be heterogeneity in terms of susceptibility to Shiga toxin.
Several lines of evidence suggest that endotoxins may contribute to the development of HUS. Bertani et al. [41] demonstrated that when rabbits were infused with $E$. coli O111:B4 LPS, marked damage to glomerular EC became apparent within $5 \mathrm{~min}$. Changes in EC morphology preceded polymorphonuclear cell infiltration and fibrin deposition. These changes were consistent with those seen in the kidneys of HUS patients [16]. Barrett et al. [48] showed that a single sublethal dose of endotoxin given to rabbits 3 days after the initiation of continuous SLT-II infusion enhances the lethal effect of the toxin. In the in vitro cytotoxicity assays reported here, however, purified LPS derived from $S$. dysenteriae type 1 or EHEC strains was not directly cytotoxic for EC at doses as high as $10 \mu \mathrm{g} / \mathrm{ml}$. This finding is in accordance with earlier studies showing that HUVEC are refractory to both LPS-mediated direct cytotoxicity and changes in EC function at doses as high as $100 \mu \mathrm{g} / \mathrm{ml}[49,50]$. In addition, we have shown that the addition of anti-Shiga toxin MAb to crude toxin preparations neutralizes cytotoxicity, and the coincubation of EC with LPS and purified Shiga toxin neither enhanced nor inhibited EC cytotoxicity. However, the correlation of our in vitro cytotoxicity data with animal models of HUS should be made with caution. The capacity of endotoxins to mediate alterations in cellular functions, particularly through the elicitation of endogenous cytokines, is now well documented $[42,51]$. Thus, the contributory effect of endotoxins in HUS may be mediated through changes in EC or inflammatory cell functions that have yet to be fully elucidated.

Our data suggest that in the presence of the cytokine $\mathrm{TNF} \alpha$, the Shiga toxin $\mathrm{EC} \mathrm{CD}_{50}$ may be reduced from 
$\sim 10^{-8} M$ to as low as $\sim 10^{-10} M$ (table 2). Although free Shiga toxin or SLTs in human sera have not been quantitated, it is not unreasonable to speculate that this lower dose of toxin may be in the physiologically relevant range [52]. In addition, Shiga toxin may exacerbate any cytotoxic effects mediated directly by cytokines. rhTNF $\alpha$ at $20 \mathrm{ng} / \mathrm{ml}$ or recombinant human interleukin- $1 \beta$ at $100 \mathrm{pg} / \mathrm{ml}$ have been demonstrated not to be directly cytotoxic for HUVEC [53]. However, in the presence of the protein synthesis inhibitor cycloheximide or the RNA synthesis inhibitor actinomycin D, HUVEC have been shown to be sensitized to the cytotoxic effects of these cytokines [53]. Therefore, by inhibiting de novo protein synthesis, Shiga toxin and SLTs may act to block the protective mechanism(s) necessary to overcome cytokine-mediated direct cytotoxicity.

We used an indirect immunofluorescence assay to monitor the binding of Shiga toxin to EC. Toxin-specific binding to EC was reduced relative to Vero and HeLa cells. We also noted cell-to-cell variations in toxin binding when Vero or HeLa cells or EC were treated with equivalent doses of Shiga toxin. Again, this suggests that the cells may consist of heterogeneous populations in terms of the capacity to bind Shiga toxin. Toxin binding studies using Shiga toxin-sensitive and resistant HeLa cell lines have shown that 10-fold differences in toxin binding sites can produce $10^{9}$-fold variability in toxin sensitivity [46, 47]. Thus, the minute differences in fluorescence we observed among cells in the toxin binding experiments may represent profound differences in Shiga toxin sensitivity. To more directly compare differences in toxin binding, we examined the glycolipid components of the cell membranes. Both EC types contained $\sim 1000$-fold less $\mathrm{Gb}_{3}$ than did Vero cells. Thus, the relative insensitivity of human EC derived from large veins may be directly correlated with reduced numbers of toxin-specific membrane receptors, and our data support earlier studies showing a correlation of Shiga toxin sensitivity with membrane $\mathrm{Gb}_{3}$ content $[45,47,54]$.

Our data demonstrating the relative insensitivity of human vascular EC to Shiga toxin and the paucity of toxin-specific membrane receptors suggest that the use of these cells may not represent the most appropriate in vitro model of HUS. Histopathologic studies have shown, however, that glomerular EC damage is a hallmark of HUS [16, 41]. Boyd and Lingwood [45] showed that $\mathrm{Gb}_{3}$ is the predominant neutral glycolipid in human renal tissue; their values were $\sim 2$ - to 30 -fold greater than the amount of $\mathrm{Gb}_{3}$ we detected in EC. Although the amount of glycolipid in a complex tissue sample may not accurately reflect the relative amount in a particular cell type, the data suggest that EC derived from large veins may differ in their toxin-receptor content from glomerular endothelial cells. Finally, it is important to note that human vascular EC and glomerular EC are functionally and morphologically distinct cells. Glomerular EC are highly fenestrated and coated with a sialoglycoprotein-rich anionic glycocalix [55]. The structural and functional differences in
EC may include differential responses to Shiga toxin or LPS. There is one report that endotoxins are directly cytotoxic for human glomerular endothelial cells [56]. Further studies on the effect of Shiga toxin and endotoxin on human glomerular cells are clearly warranted and are currently in progress in our laboratory.

\section{Acknowledgments}

We thank Stefanie Vogel for helpful discussions; David Silverman, Abla Creasey, and the Operating Room staff of Washington Adventist Hospital for assistance in obtaining tissues and reagents; Wei Du, Pin Yu Perera, and Thomas Sellner for technical assistance; and Elizabeth Leach for art work.

\section{References}

$\rightarrow$ Bennish ML, Harris RJ, Wojtyniak BJ, Struelens M. Death in shigellosis: incidence and risk factors in hospitalized patients. J Infect Dis 1990;161:500-6.

2. Riley LW, Remis RS, Helgerson SD, et al. Hemorrhagic colitis associated with a rare Escherichia coli serotype. N Engl J Med 1983;308:681-5.

3. Pai CH, Gordon R, Sims HV, Bryan LE. Sporadic cases of hemorrhagic colitis associated with Escherichia coli O157:H7. Clinical, epidemiologic, and bacteriologic features. Ann Intern Med 1984;101:738-42.

4. Strockbine NA, Jackson MP, Sung LM, Holmes RK, O'Brien AD. Cloning and sequencing of the genes for Shiga toxin from Shigella dysenteriae type 1. J Bacteriol 1988; 170:1116-22.

5. Strockbine NA, Marques LRM, Newland JW, Williams Smith H, Holmes RK, O'Brien AD. Two toxin-converting phages from Escherichia coli $\mathrm{O} 157: \mathrm{H} 7$ strain 933 encode antigenically distinct toxins with similar biological activities. Infect Immun 1986;53:135-40.

6. Jackson MP, Neill RJ, O'Brien AD, Holmes RK, Newland JW. Nucleotide sequence analysis and comparison of the structural genes for Shiga-like toxin I and Shiga-like toxin II encoded by bacteriophages from Escherichia coli 933. FEMS Microbiol Lett 1987;44:109-14.

7. O'Brien AD, Holmes RK. Shiga and Shiga-like toxins. Microbiol Rev 1987;51:206-20.

8. Endo Y, Tsurugi K, Yutsudo T, Takeda Y, Ogasawara T, Igarashi K. Site of action of a Vero toxin (VT2) from Escherichia coli O157:H7 and of Shiga toxin on eukaryotic ribosomes. RNA $\mathrm{N}$-glycosidase activity of the toxins. Eur J Biochem 1988;171:45-50.

9. Saxena SK, O’Brien AD, Ackerman EJ. Shiga toxin, Shiga-like toxin II variant, and ricin are all single-site RNA $N$-glycosidases of $28 \mathrm{~S}$ RNA when microinjected into Xenopus oocytes. J Biol Chem 1989; 264:596-601.

10. Lindberg AA, Schultz JE, Westling M, et al. Identification of the receptor glycolipid for Shiga toxin produced by Shigella dysenteriae type 1 . In: Lark D, ed. Protein-carbohydrate interactions in biological systems. London: Academic Press, 1986:439-46.

11. Jacewicz M, Clausen H, Nudelman E, Donohue-Rolfe A, Keusch GT. Pathogenesis of Shigella diarrhea. XI. Isolation of a Shigella toxinbinding glycolipid from rabbit jejunum and HeLa cells and its identification as globotriaosylceramide. J Exp Med 1986;163:1391-404.

12. Lingwood CA, Law H, Richardson S, et al. Glycolipid binding of purified and recombinant Escherichia coli produced verotoxin in vitro. $\mathbf{J}$ Biol Chem 1987;262:8834-9.

13. Waddell T, Head S, Petric M, Cohen A, Lingwood C. Globotriosyl ceramide is specifically recognized by the Escherichia coli verocytotoxin 2. Biochem Biophys Res Commun 1987;152:674-9.

14. Fontaine A, Arondel J, Sansonetti PJ. Role of Shiga toxin in the patho- 
genesis of bacillary dysentery, studied by using a tox ${ }^{-}$mutant of Shigella dysenteriae 1. Infect Immun 1988;56:3099-109.

15. Cleary TG. Cytotoxin-producing Escherichia coli and the hemolytic uremic syndrome. Pediatr Clin North Am 1988;35:485-99.

16. Richardson SE, Karmali MA, Becker LE, Smith CR. The histopathology of the hemolytic uremic syndrome associated with verocytotoxin-producing Escherichia coli infections. Hum Pathol 1988; 19:1102-8.

17. Gerlach H, Esposito C, Stern DM. Modulation of endothelial hemostatic properties: an active role in the host response. Annu Rev Med 1990;41:15-24.

18. Obrig TG, Del Vecchio PJ, Brown JE, et al. Direct cytotoxic action of Shiga toxin on human vascular endothelial cells. Infect Immun 1988;56:2373-8.

19. Mata LJ, Gangarosa EJ, Caceres A, Perera DR, Mejicanos ML. Epidemic Shiga bacillus dysentery in Central America. I. Etiologic investigations in Guatemala. J Infect Dis 1969:122:170-80.

20. Perera LP, Samuel JE, Holmes RK, O'Brien AD. Identification of three amino acid residues in the B subunit of Shiga toxin and Shiga-like toxin type II that are essential for holotoxin activity. J Bacteriol 1991;173:1151-60.

21. Newland JW, Strockbine NA, Neill RJ. Cloning of genes for production of Escherichia coli Shiga-like toxin type II. Infect Immun 1987;55:2675-80.

22. Samuel JE, Perera LP, Ward S, O'Brien AD, Ginsburg V, Krivan HC. Comparison of the glycolipid receptor specificities of Shiga-like toxin type II and Shiga-like toxin type II variants. Infect Immun 1990;58:611-8.

23. Recombinant DNA research guidelines. Fed Register 1986;51:16972.

24. Westphal O, Jann K. Bacterial lipopolysaccharides. Extraction with phenol-water and further applications of the procedure. In: Whistler RC, ed. Carbohydrate chemistry. Vol 5. New York: Academic Press, 1965:83-91.

25. O'Brien AD, LaVeck GD. Purification and characterization of Shigella dysenteriae 1-like toxin produced by Escherichia coli. Infect Immun 1983;40:675-83.

26. Watkins MT, Sharefkin JB, Maciag TM, et al. Adult human saphenous vein endothelial cells: assessment of their reproductive capacity for endothelial seeding of vascular prostheses. J Surg Res 1984;36:58896.

$\rightarrow$ Glaser BA, D'Amore PA, Michels RG, Patz A, Fenslau A. Demonstration of vasoproliferative activity from mammalian retina. J Cell Biol 1980;84:298-304.

28. Sharefkin JB, Fairchild KD, Albus RA, Cruess DF, Rich NM. The cytotoxic effect of surgical glove powder particles on adult human vascular endothelial cell cultures: implications for clinical uses of tissue culture techniques. J Surg Res 1986;41:463-72.

29. Gentry MK, Dalrymple JM. Quantitative microtiter cytotoxicity assay for Shigella toxin. J Clin Microbiol 1980;12:361-6.

30. Brasaemle DL, Attie AD. MicroELISA reader quantitation of fixed, stained, solubilized cells in microtitre dishes. BioTechniques 1988;6:418-9.

31. Holmes RK, Twiddy EM. Characterization of monoclonal antibodies that react with unique and cross-linking determinants of cholera enterotoxin and its subunits. Infect Immun 1983;42:914-23.

32. Hogan MM, Perera PY, Vogel SN. Examination of macrophage cell surface antigen regulation by $\operatorname{rIFN}-\gamma$ and IFN- $\alpha / \beta$ utilizing digital imaging by a novel laser detection system. Anchored cell analysis station (ACAS) 470. J Immunol Methods 1989;123:9-18.

33. Griffin DE, Gentry MK, Brown JE. Isolation and characterization of monoclonal antibodies to Shiga toxin. Infect Immun 1983;41: 430-3.

34. Strockbine NA, Marques LRM, Holmes RK, O'Brien AD. Characterization of monoclonal antibodies against Shiga-like toxin from Escherichia coli. Infect Immun 1985;50:695-700.

35. Downes FP, Barrett TJ, Green JH, et al. Affinity purification and char- acterization of Shiga-like toxin II and production of toxin-specific monoclonal antibodies. Infect Immun 1988;56:1926-33.

36. Magnani JL, Smith DF, Ginsburg V. Detection of gangliosides that bind cholera toxin: direct binding of ${ }^{125}$ I-labeled toxin to thin-layered chromatograms. Anal Biochem 1980;108:399-402.

37. Libby P, Ordovas JM, Auger KR, Robbins AH, Birinyi LK, Dinarello CA. Endotoxin and tumor necrosis factor induce interleukin-1 gene expression in adult human vascular endothelial cells. Am J Pathol 1986; 124:179-85.

38. Schleimer RP, Rutledge BK. Cultured human vascular endothelial cells acquire adhesiveness for neutrophils after stimulation with interleukin 1, endotoxin, and tumor-promoting phorbol diesters. J Immunol 1986;136:649-54.

39. Loppnow H, Libby P. Adult human vascular endothelial cells express the IL-6 gene differentially in response to LPS or IL-1. Cell Immunol 1989;122:493-503.

40. Koster F, Levin J, Walker L, et al. Hemolytic-uremic syndrome after shigellosis. Relation to endotoxemia and circulating immune complexes. N Engl J Med 1978;298:927-33.

41. Bertani T, Abbate M, Zoja C, Corna D, Remuzzi G. Sequence of glomerular changes in experimental endotoxemia: a possible model of hemolytic uremic syndrome. Nephron 1989;53:330-7.

42. Larrick JW, Kunkel SL. The role of tumor necrosis factor and interleukin 1 in the immunoinflammatory response. Pharm Res 1988; 5:129-39.

43. Fuchs G, Mobassaleh M, Donohue-Rolfe A, Montgomery RK, Grand RJ, Keusch GT. Pathogenesis of Shigella diarrhea: rabbit intestinal binding site for Shigella toxin. Infect Immun 1987;53:372-7.

44. Donohue-Rolfe A, Jacewicz M, Keusch GT. Isolation and characterization of functional Shiga toxin subunits and renatured holotoxin. Mol Microbiol 1989;3:1231-6.

45. Boyd B, Lingwood C. Verotoxin receptor glycolipid in human renal tissue. Nephron 1989;51:207-10.

46. Eiklid K, Olsnes S. Interaction of Shigella shigae cytotoxin with receptors on sensitive and insensitive cells. J Recept Res 1980;1:199-213.

47. Jacewicz M, Feldman HA, Donohue-Rolfe A, Balsubramanian KA, Keusch GT. Pathogenesis of Shigella diarrhea. XIV. Analysis of Shiga toxin receptors on cloned HeLa cells. J Infect Dis 1989;159:881-9.

48. Barrett TJ, Potter ME, Wachsmuth IK. Bacterial endotoxin both enhances and inhibits the toxicity of Shiga-like toxin II in rabbits and mice. Infect Immun 1989;57:3434-7.

49. Harlan JM, Harker LA, Striker GE, Weaver LJ. Effects of lipopolysaccharides on human endothelial cells in culture. Thromb Res 1983;29:15-26.

50. Harlan JM, Harker LA, Reidy MA, Gajdusek CM, Schwartz SM, Striker GE. Lipopolysaccharide-mediated bovine endothelial cell injury in vitro. Lab Invest 1983;48:269-74.

51. Morrison DC, Ryan JL. Endotoxins and disease mechanisms. Annu Rev Med 1987;38:417-32.

52. Kaplan BS, Cleary TG, Obrig TG. Recent advances in understanding the pathogenesis of the hemolytic uremic syndromes. Pediatr Nephrol 1990;4:276-83.

53. Pohlman TH, Harlan JM. Human endothelial cell response to lipopolysaccharide, interleukin-1, and tumor necrosis factor is regulated by protein synthesis. Cell Immunol 1989;119:41-52.

54. Cohen A, Hannigan GE, Williams BRG, Lingwood CA. Roles of globotriosyl- and galabiosylceramide in verotoxin binding and high affinity interferon receptor. J Biol Chem 1987;262:17088-91.

55. Bulger RE, Hebert SC. Structural-functional relationships in the kidney. In: Schrier RW, Gottschalk CW, eds. Diseases of the kidney. Boston: Little, Brown, 1988:3-63.

56. Raghu G, Striker LJ, Striker GE. Lipopolysaccharide-mediated injury to cultured human glomerular endothelial cells. Clin Immunol Immunopathol 1986;38:275-81. 